\title{
Strengthening the Border Tourism in Sambas District of West Kalimantan Indonesia in the Covid-19 Pandemic: A Political Boundaries Perspective
}

\author{
Elyta Elyta ${ }^{1, *}$ Wahyuni Kartikasari ${ }^{2}$
}

\author{
${ }^{1}$ Universitas Tanjungpura Pontianak, Indonesia \\ ${ }^{2}$ Universitas Muhammadiyah Yogyakarta, Indonesia \\ *Corresponding author. Email: elyta@fisip.untan.ac.id
}

\begin{abstract}
The Covid-19 pandemic has hurt global tourism, including in Indonesia. Covid-19 has made tourism actors aware to be wise in managing natural and cultural resources. This research was conducted to analyze the strengthening of border tourism during Covid-19 from a political boundary perspective. This study uses a descriptive method with a qualitative approach. The data in this study were obtained through interviews and literature study. The informants in this study are the Regent of Sambas, Deputy Regent of Sambas, Head of the Department of Tourism and Marketing of the Sambas Regency for Youth and Sports, Head of the Destination Section of the Sambas Regency Youth and Sports Tourism Office, Generation of Pesona Indonesia (GenPI), and community leaders. Literature studies were obtained from journals and online news about border tourism during Covid-19 from a political boundaries perspective. This study found that based on strengthening border tourism during Covid-19, it has been carried out through political boundaries perspective by (1) understand and implement the Covid-19 border tourism adaptation policy, (2) strengthening the political potential of border tourism during Covid-19, and (3) developing digital-based border tourism during Covid-19.
\end{abstract}

Keywords: Border Tourism 1, Covid-19 2, Political Boundaries 3

\section{INTRODUCTION}

Tourism is a multidimensional and multifaceted activity that touches many lives and many different economic activities [1]. Tourist attractions can be in the form of art, culture, nature, historical heritage, sports, or objects that are still natural or have received the human intervention [2]. Like all operations that produce goods and services, tourism operations aim to achieve the highest profit by making the best use of available resources. Since production and consumption are simultaneous in the tourism industry, the profitability of the tourism operation is highly dependent on the demand to be attracted. Tourism demand can be easily affected by adverse conditions in the tourism environment [3].

This study uses an analytical knife that is based on the perspective of the political boundaries. This theory states that there are several other phenomena related to political boundaries perspectives, namely (1) crossborder shopping opportunities, (2) bordertown gambling, (3) welcome centers, and (4) international pockets. Cross-border shopping opportunities is regarded as a pleasure-based mode of leisure travel for many individuals and a major driver of tourism in border areas. Bordertown gambling is the situations offers enough opportunities for in-state border gambling communities to draw significant numbers of people from neighboring off-state areas by constructing gambling in the boundaries. Tourist information buildings or reception centres along major highways at or near their borders are welcome centres. International pockets is eclave/enclave, which is a small portion of a country entirely surrounded by the territory of another country [4]. This phenomenon is an opportunity for tourism on the border to develop, including when facing the global Covid-19 pandemic.

The outbreak of Coronavirus 2019 or Covid-19 caused by the SARS-COV-2 virus started in Wuhan, China, at the end of December 2019, which has resulted in many chaoses including triggering the global economic crisis [5]. This in turn has a very real impact 
on the tourism sector, which is very important for many people, places, and businesses, with impacts, particularly felt in countries, cities, and regions where tourism is an important part of the economy.

Politically, every element of the government that is formed functions to provide its services to the public [6]. Governments around the world have pursued unprecedented steps to contain the virus, travel restrictions, business operations, and person-to-people interactions that have brought the tourism economy to a halt. Many countries are now entering a new phase in fighting the virus while at the same time reopening their tourism economy. This is a complex and challenging task, and it is difficult to quantify the impact on the tourism economy.

In 2016, Asia Pacific led the growth of tourist arrivals worldwide at $9 \%$ followed by Africa at $8 \%$ and America at $3 \%$. The number of tourists coming to Asia increased by 23.1 million, from 269.7 million in 2015 to 292.8 million in 2016. The area is estimated by the United Nations World Tourism Organization (UNWTO) to receive an additional 535 million tourists by the end of the year 2030 [7].

Challenges and opportunities always arise in every extraordinary event. The biggest challenge is how can tourism be able to bounce back with a health protocol that can minimize the transmission of Covid-19? True tourism is the movement of people, human relations, sharing experiences, and even sharing knowledge, fun, and satisfaction ending with a warm hug as a memory that will always be remembered. Now, Covid-19 forces us to adjust our distance in socializing, use masks to protect the environment, food, and so on. Tourism is forced to adapt to new realities and of course, this adaptation will be very much up to the managers and tourists themselves.

January-April 2020 the number of tourists reached 2.77 million visits or decreased compared to the number of foreign tourists visiting in the same period in 2019 which amounted to 5.03 million visits [8]. International tourism is a tourism category in which tourists have a longer radius of motion outside the national boundaries of the territory they live in continuously and whereas the economic impact of this type of tourism is significantly higher than that of domestic tourism. Almost all international tourists perform the same three activities for them, and with which we can measure the dimensions of international tourism [9]. Based on projections made by the Indonesian government, it shows that tourism is proclaimed as one of the priority sectors for development in the next five years. This is expected to be the number one foreign exchange contributor in Indonesia in 2020. To achieve this, the government is making big projections, including accelerating development in the tourism line through a program of 10 priority tourism destinations which are divided into National Tourism Strategic Areas and Special Economic Zone for Tourism or what is called the "10 New Bali" [10].

The epidemic that originated in the city of Wuhan, China has made Indonesian tourism lose its many tourists. This can be seen from the number of realized foreign tourist arrivals during 2019 which reached 16.3 million. Of these, $12 \%$ of tourists came from China [8]. Since the pandemic, the number of foreign tourists to Indonesia has decreased drastically. Based on this background, this research was conducted to answer the question "How were efforts to strengthening border tourism during Covid-19 from a political boundaries perspective?"

\section{METHODS}

This research was conducted to examine the strengthening of border tourism during Covis 19 from a political perspective. This research was conducted from March 2020 to September 2020 using qualitative methods. Qualitative methods are carried out by conducting interviews with informants and by studying literature. Literature studies are used by examining written sources from online journals and news regarding the strengthening of border tourism during Covis 19 from a political perspective. Resource persons in this study were the Regent of Sambas, Deputy Regent of Sambas, Head of Institutions and Marketing at the Department of Tourism, Youth and Sports of Sambas Regency, Head of the Destination Section at the Department of Tourism, Youth and Sports of Sambas Regency, GenPi Management, and community leaders.

\section{RESULTS AND DISCUSSION}

Strengthening border tourism during Covid-19 by a political boundaries perspective through:

\subsection{Understand and Implement the Covid-19 Border Tourism Adaptation Policy}

In the framework of global tourism development, tourism strategic planning is needed [11]. Strategic documents are very important because they represent a powerful mechanism and tool for making tourism policies [12]. Resource management, both natural resources and human resources, also needs to be done so that the border area can experience optimal development [13]. Several border tourism adaptation policies during Covid-19 refer to the Covid-19 pandemic health protocol that must be adopted by both tourists and tour managers, including checking body temperature, wearing masks, and maintaining distance when socializing. With security issues increasing in the aftermath of a terrorist attack, travellers have to adjust to increasingly stringent inspections at airports, malls, and office buildings. This protocol ensures that people 
do not carry sharp objects or liquids deemed dangerous. This eventually became a new habit which was adapted by all users of aviation services, hotels, malls, or office buildings to date.

In the future, it is possible to check body temperature, use masks, and maintain distance to become new habits, which eventually change our old habits, for example by no longer shaking hands when we meet, but smiling, nodding, and greeting hands on our chests. Don't be afraid to interact with tourists, as long as you follow health protocols. Cleanliness, Protocols, and Health Facilities in major destinations and tourist attractions are considered by tourists to visit. Therefore, managers of tourist attractions need to adjust the management of their visitors by training tourist attraction managers to understand health protocols. Require officers and visitors to wear masks and disseminate health protocols to potential visitors.

Covid-19 reminds us that tourism is not everything. Tourism is affected by external factors such as infectious diseases; climate change, terrorism, social/political conflict, etc. So that destination resilience should not only rely on the tourism sector, but it is necessary to combine its development with other sectors, such as creative industries, agriculture, plantations, or fisheries. Covid-19 forces us not to ignore the standards of excellent service, hygiene, and health. Tourism is a service sector, which relies heavily on services and people who serve. Standards are instruments for controlling the quality of service, so they should be applied to ensure a quality tourist experience. Accurate information is one of the hopes of all tourists.

The Covid health protocol regulates the movement of people (maintaining distance, wearing masks, checking body temperature, and washing hands). This protocol needs to be adopted and adapted in managing visitors, such as regulating quotas, dividing large groups into small groups during tourist activities, providing handwashing facilities, maintaining environmental cleanliness, safe Covid-19. Less aware that nature and culture are tourism business assets that must be cared for sustainability. Covid-19 increases our solidarity and the importance of networking. The pandemic period has increased the sense of solidarity between people to fight the virus and also help each other in difficult times. This reminds us of the importance of networking, and the tourism business is known as a tourism chain, where a strong network between actors is needed.

Covid-19 reminds the importance of Destination Institutions. Management institutions and management systems are important components of sustainable tourism. Customer data is very important in tourism for business development and also important in difficult times because it is necessary to maintain customer trust to maintain a business in the post-pandemic period.
Covid-19 also reminds us of the importance of risk mitigation. The tourism business is greatly influenced by external factors that occur beyond the ability of the manager. Therefore management needs to mitigate to reduce the risk of loss or bankruptcy caused by external factors.

\subsection{Strengthening the Political Potential of Border Tourism During Covid-19}

In this study, researcher found that to strength the border tourism during Covid-19 by a political boundaries perspective through is not only by increase potency on (1) cross-border shopping opportunities, (2) border gambling, (3) welcome centers, and (4) international pockets, but also by increase potency on (1) cross-border economic needs; (2) natural and human resources, and (3) cross-border tourist attraction events. This is further explained in the following chart and explanation.

Figure 1. Political Potential of Border Tourism During Covid-19

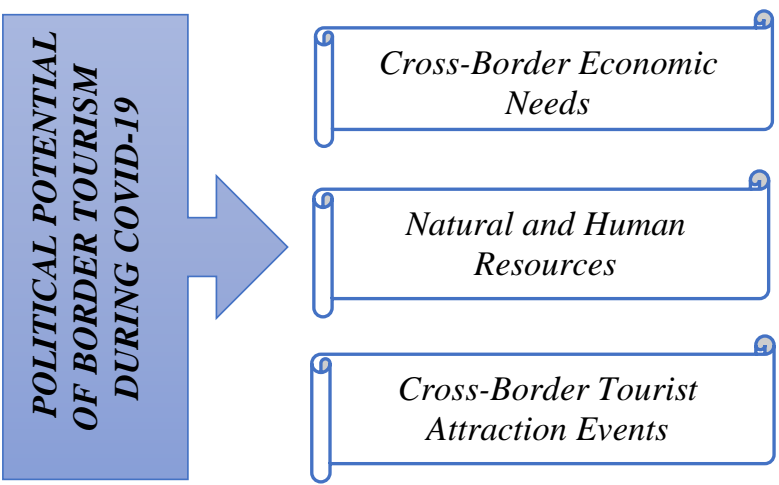

Source: Processed by researchers (2020)

\subsubsection{Cross-Border Economic Needs}

In many regions of the world, cross-border shopping is a common activity. People have crossed political boundaries for years in order to shop. For a number of perceived benefits, including lower prices and taxes and a wider or different selection of goods, shopping malls, grocery stores and gas stations often draw individuals from across administrative borders. Based on political boundaries perspective, these are called cross-border shopping opportunities [4]. Furthermore, this study found that these things were analyzed as the economic needs of people across borders or what were called cross-border economic needs.

The development of tourism destinations must be supported by the potential for tourism activities [14]. Tourism is considered a very important activity as occurs in other sectors of the world economy, activities such as agriculture or industry, or trade. Due to the scale and various elements, but also because of the value and 
originality of these elements, tourism becomes the main motivation of all of them, tourist traffic. A certain area or landmark is an attraction to travel as far as it can provide tourist activities. The tourism potential of an area can be interpreted as all the elements that make up a tourist spot with facilities to receive tourist representatives [15].

People have crossed political lines for years in order to shop. For a variety of perceived advantages, including lower rates and taxes and a broader or different range of products, shopping centers, grocery stores and gas stations also attract individuals from across administrative boundaries. In addition to shopping (both focused on fun and economics), many cross-border shoppers also involve activities such as watching movies in a cinema, visiting museums and historical or natural attractions, dining in restaurants, using public transport, and spending the night in local hotels for those staying for more than one day [4]. International cross-border shopping is therefore not only an economic practice, it can also be seen in many cases as a pleasure-based mode of leisure travel for many people and a significant generator of tourism in border areas.

Tourism development is important to do. aims to regulate and facilitate tourism practices in the community, with provision for the community in managing tourism potential in the village, indirectly increasing the economy of the people in the village, and helping local tourism sources in the village [16].

Apart from determining policies and programs, the central and local governments are increasingly concrete management of the tourism potential of Sambas Regency through strengthening various aspects, one of which is social. There is still a lack of education and training facilities in tourism activities, so that the ability to manage the types of activities that can be carried out, implementation time, group coverage or composition, visitor expectations, and characteristics of the location (tourism destination) are still in the weak category. This means that there is a limited ability to conduct an assessment of policy activities related to the implementation of tourism, from strategic policy formulation to technical tourism operations in Sambas district.

\subsubsection{Natural and Human Resources}

Based on the results of research interviews, the Deputy Regent of Sambas District emphasized that the management of cross-border tourism is not only related to infrastructure matters but also the quality of available human resources. Especially in the current era of globalization, some Indonesians are interested in becoming migrant workers to obtain a more decent life. The informant presented data on the flow of migrant workers which reached more than 35,000 Indonesian workers (TKI) who predominantly work in Malaysia. Of course, this is a challenge in itself for Indonesia, especially in cross-border areas to compete in the realm of employment. Thus, improving the quality and distribution of human resources requires support or encouragement from the procurement of various constructive activities.

Atbah Romin Suhaili as Regent of Sambas said the government urged residents to be actively involved in managing cross-border tourism in Sambas Regency. The involvement referred to refers to the empowerment of human resources in promoting border tourism promotion and maintaining the existence of border tourism in a competitive market. This social project is aligned with regulations or policies set by the government, to be able to achieve national interests that make the community prosperous, such as accelerating economic improvement.

The government's policy practices that are harmonized with social projects can be seen through the provision of training for residents, especially youth in Sambas District. This training fosters the community to be ready and adapt or qualify themselves to the demands of jobs available in border areas, such as business actors and experts who can master foreign languages, at least English, and know export and import strategies as well as computerization. Of course, there is also an appeal to the community to take an active role in preserving and supporting tourist destination facilities. The role of the government is indeed important in managing the potential for border tourism, but community action is very influential as well.

In reality, government promotions will fail when the offered destinations do not provide comfort, which includes unattended environmental cleanliness, natural damage, and minimal maintenance of facilities. This means that in reality, the government is not the party directly involved in the practice of environmental problems in tourist attractions, but the settlers in the vicinity who need to conserve and help the development of cross-border tourism in a real way. The synergy between the government and local communities can build more stable management of cross-border tourism and can continue to exist in the competition for tourism at the global stage.

Besides, there are target demands regarding the presentation of various superior products from Sambas Regency such as handicraft products from Micro, Small, and Medium Enterprises, agricultural commodities, and tourism profiles that can be promoted to attract visitors. This target is realized through the Wonderful Indonesia agenda which is followed up with several evaluations from the Ministry and meetings involving local governments to prepare a cross-border market program or the 2020 Cross-border Market which will be 
positioned at each point of the National Cross-Border Post, one of which is in Aruk, Sambas Regency.

Furthermore, it is believed that the formation of the Co-Branding strategy encourages the government, especially the Ministry of Tourism, to follow up on Sirikin and directly observe several destination locations, including market locations that are the target of the Weekend Market. The weekly market is a contemporary idea that is alleged to increase tourism potential as well as inviting foreign tourists to the border area through the cooperation of the central government with the regions. This co-branding practice will improve the welfare of border communities in the economic sector because it opens profitable business opportunities, such as lodging and culinary destinations [17].

The Head of Marketing and Tourism Institutions at the Sambas Regency Tourism, Youth and Sports Office, Tegus added that the progress of the Cross-border Market program in Aruk is currently facing core administrative matters. In contrast to the implementation of the Belampar Market which is generally held weekly, the current market program has a limitation on the implementation period targeted at the first week of each month. Therefore, it requires committed and mature preparation from the Sambas Regency government and ministries related to the formation of concepts and field techniques, such as the problem of tents, contemporary or contemporary market models but there are traditional elements, including the participation of the Education and Culture Office in the form of entertainment attractions that become a visitor attraction.

Based on the views of the Head of Marketing and Tourism Institutions, alternative government practices are increasingly being influenced by the role of society. It is pointed out that the surrounding community has taken part by producing and selling typical Sambas Regency products so that it becomes the attraction of visitors. In contrast to the government which functions as a promotional media and festival organizer, the community participates in the agenda and evaluation of festival activities. Various communities or institutions also play a role in the implementation of activities, such as the KKN activities from UMS and other universities at the Smoky Riam with the theme of tourism.

\subsubsection{Cross-Border Tourist Attraction Events}

Cross-border areas often share similarities with natural conditions. However, it also has different socioeconomic conditions. If they have the right potential for tourism development, they can carry out joint activities aimed at increasing tourism attractiveness data from cross-border areas and can contribute to stimulating economic development [18].
In 2019 the government through the Ministry of Tourism of the Republic of Indonesia is increasingly paying attention to the development of cross-border tourism through the implementation of local, national, regional, and global tourism events [19]. Several promotional efforts have been carried out intensively, such as the event The Wonderful Indonesia Beach Festival on 21-22 January 2017 at St. Kilda Beach, Melbourne Australia, and Rhythm of The Spring Festival in China. The event successfully attracted the attention of visitors and strengthened the relationship between Indonesia and Australia through culture, music, culinary and tourism and in the context of welcoming the Chinese New Year's Eve event. At the event,

The Special Staff of the Minister of Tourism for Information Technology, Samsriyono, said that there were three formulations of marketing strategies that had to be implicated. These strategies are naming advertising, and sales or abbreviated as BAS (Branding, Advertising, and Selling). From the three strategies, and implementation program was launched through access incentives, hot deals, CDM (Competing Destination Model), the Border Tourism program, Tourism Hub, and Low-Cost Terminal [20]. This is also in line with the Independent Village program that is being echoed by the government, including in West Kalimantan by Governor Sutarmidji. He stated that the quality of human resources in West Kalimantan must be improved to develop the tourism sector, especially in the border areas, and in line with the indicators of Independent Village. One of these indicators is an increase in literacy.

According to Sutarmidji at the National Literacy Tour activity on September 7, 2019, in Pontianak, he revealed that in the next few years there will be the availability of 2,031 reading houses in West Kalimantan that contain reading material and literature in them [21]. The local government through the West Kalimantan Youth, Sports, and Tourism Office in early 2019 launched the West Kalimantan Tourism Event Calendar which can be accessed publicly via the internet. The tourism activity calendar contains information about what tourist events will be held in West Kalimantan Province.

\subsection{Developing Digital-Based Border Tourism during Covid-19}

Technology is revolutionizing the tourism industry and determining the strategies and competitiveness of tourism organizations and destinations. Regarding the development of tourism through digital or digital tourism, it is defined as tourism that is supported by digital technology before, during, and after tourism activities are carried out [22]. 
According to the United Nation in the Conference on Trade and Development access to digital information technology can use various forms of media from mobile phones, internet channels, GPS (Global Positioning System), digital cameras, digital radios, and digital media players. The use of digital information technology facilitates communication in tourism [22] proposes that current tourist destinations must-have digital capabilities. Digital capabilities are crossfunctional capabilities in the processes, practices, and customer connections made possible by digital media and infrastructure.

There are four dimensions of the use of digital technology in tourism, namely: (1) Provision of information on tourist attraction objects. Provision of information consists of interpretation of tourist attraction objects (ODTW), provision of travel schedules, and provision of maps for the movement of tourists, accommodation, and tourist facilities; (2) The ability to share information. The ability to share information must come from two sources, namely from tourism providers as suppliers and also from tourists as consumers; (3). Context-awareness Context awareness is the awareness of digital tourism culture for the community so that the availability of attractions or facilities, clarity of information and directions on tourist sites using digital technology;

To stop its spread, many countries have made policies to stop international flights, force residents to work from home, wear masks, and maintain social distancing. We are forced to have a new "habit" which is called a new normal, a new thing outside of our old habits, but then it becomes a new habit or new normal. This habit will certainly affect tour activities because it is required to implement health protocols at airports, hotels, homestays, tourist attractions, and during activities. Information on the principles of Ecotourism and how to adapt it for managers of tourist attractions, homestays, and managers of ecotourism activities, is expected to be of benefit to Indonesia's ecotourism network and tourism actors in general. All levels of society, including tourism managers, must be subjects to prevent the spread of Covid-19 to achieve a safe Covid19 destination.

Sambas Regency itself currently has 95 destination objects consisting of natural and cultural tourism objects. The potential of the Sambas Regency itself in the tourism sector is very rich and diverse. This huge potential will certainly support the economic growth of the community and local revenue if it is managed with optimal development. One of the objects with considerable potential is the cross-border area.

Tourism can create large economic benefits for host countries by contributing to government revenue and creating jobs and business opportunities [1]. The implementation of festivals in the West Kalimantan border area by the government before Covid-19 has achieved good results in attracting visitors. Supported by various media that support the promotion of crossborder tourism, tourists are starting to explore border tourism, especially in Aruk. No less than other destinations that are generally well-known, the natural charm of Air Tejun Riam Merasap is one of the exotic tourism locations of Sambas Regency, decorated with a panoramic view of the special tropical forests of Kalimantan, also equipped with facilities for visitor convenience.

In this case, creative tourism is seen as an alternative to the tourism area as a strong strategy for tourism development in the creative tourism literature [23]. Tourism space is part of the geographical space where tourism is observed [24]. Tourism space that exists, among others, Riam Merasap Waterfall, other crossborder tourism which is becoming known is Lake Semedang, Tanjung Kemuning Beach, Bukit Raya Putri Serai Beach, Selimpai Beach, Dungun Laut Beach, and Camar Wulan Beach. The natural charm of this border can attract tourists from Malaysia as well as other countries because of the affordability of the location which only takes three hours to travel from across the border of Sambas Regency. Foreign tourists who drive private vehicles to enjoy the charm of cross-border tourism have the convenience of traveling overland due to improvements and developments in infrastructure in the Indonesian border area [25].

The excitement of the festival that was held previously continues to invite local visitors and those from neighboring countries to explore the natural charm of Indonesia's borders. The Deputy Regent of Sambas Regency stated that the Temajuk destination provides a sanctuary for turtles to lay eggs decorated with natural charms such as blue skies, white sand, granite rocks, and coral piles that can climb tourists. Visitor comfort is also prioritized through the provision of adequate facilities such as lodging, restaurants, sundries shop, and others.

This condition invites foreign tourists not only to visit destinations in big cities that have been well known before but also in the border areas of Indonesia. Of course, this impact reflects the successful synergy between the government and other parties in managing cross-border tourism. The government has facilitated the promotion of destinations through the provision of festivals and infrastructure assistance to facilitate the travel of tourists to tourist sites. It was further identified, it was also seen that there was assistance from the media in disseminating information on the charm of crossborder tourism that is widely owned by Indonesia, as well as the community who helps manage tourism spots such as preserving nature.

Apart from offering tour packages, the efforts of the Indonesian side in attracting foreign tourists to visit 
cross-border tourism can be seen from the presentation of the craft corner at the festival. The souvenir products offered have the uniqueness of West Kalimantan which is unique at affordable prices for young people so that visitors are interested in buying and of course want to know more about the area of origin of the product. Meanwhile, culinary attractions such as coffee, herbal medicine, and others are also equally attractive to attract festival visitors. The appearance of the manufacturing process, the introduction, and the tasting of processed consumption with Indonesian flavors has further increased the enthusiasm of foreign tourists. This is a fairly competitive selling point for border areas compared to other areas. Micro, Small, and Medium Enterprises (MSMEs) of residents to match market demand.

Indonesia is in the position 97 of the survey about the level of state security during the Covid-19 period [26]. Based on the data above, it shows that Indonesia can be a reference for travelers/tourists. Some of the assumptions that emerge about tourism in the New Normal era include (1) Going to tourist attractions is the most desirable activity (Alvara research center), (2) Domestic tourism becomes prevention, (3) Young tourists from the upper-middle class are more eager to travel, (4) Natural tourism objects are more popular for tourism, and (5) Consumers need new tourism experiences-individually based. The results of the study found five things. The first is going to a tourist spot is the most desirable activity. That of course everyone wants, especially people in countries that are affected by lockdown. Second, domestic tourism becomes prevention; for the people of Indonesia, it has just been separated from the lockdown system implemented by the government.

Tourism products and services provide a major pull factor for recreational tourism demand [27]. Tourists are looking for experiences that are different from the ones they have in everyday life. They are consumers who buy a tourism product, using geographic and social-spatial assets, which are prepared in an appropriate way [28]. Apart from the event, the Minister of Tourism, Arief Yahya also emphasized cultivating the potential of cross-border tourism through promotion through the information available in the media or electronic products. Being in a cross-border area is not an obstacle for border areas like Aruk to develop its tourism sector. Because the potential of natural resources is supported by geographical conditions in Aruk. Aruk is a hamlet located in Sebunga Village, Sajingan Besar District. Sajingan Besar District is directly adjacent to Sarawak (East Malaysia).

However, it is unfortunate that Sambas Regency is not one of the destinations in the program. Even though the potential for cross-border tourism in Aruk needs attention to be increased through this digital-based tourism potential. Utilization of the potential for digitalbased tourism is also carried out through the role of the government through the Sambas Regency Tourism, Youth and Sports Office as well as with the contribution and empowerment of youth through the Pesona Indonesia Generation. The government focuses this utilization by managing public screens (such as Videotron) and website pages. The local government of Sambas Regency already has a website page whose main function is to share information with the public, especially potential tourists, about what the tourism potential is in Sambas Regency, including in the Aruk border area. Meanwhile, Generasi Pesona Indonesia focuses on management through internet social media. Currently, utilization through the application has not been implemented because the application is not yet available in Sambas Regency.

Based on the results of research through interviews with the Head of Marketing and Tourism Institutions at the Sambas Regency Tourism, Youth and Sports Office said that the community carries out tourism activities and evaluates them. Meanwhile, the government supports in terms of promoting and holding events by inviting institutions or communities that wish to join. Besides, he also revealed that there were several activities from universities where they had held Real Work Lectures including Thematic Real Work Lectures. The Real Work Lecture raised the theme of tourism. The students saw the existing tourism potentials such as the Smoky Riam and the Dance Festival. However, this potential has not been managed with more modern methods by the demands of current technological developments. For this reason, it is necessary to strengthen digital-based tourism information systems that take advantage of technological developments with the following methods. 
Figure 2. Information Systems on Digital-Based Tourism

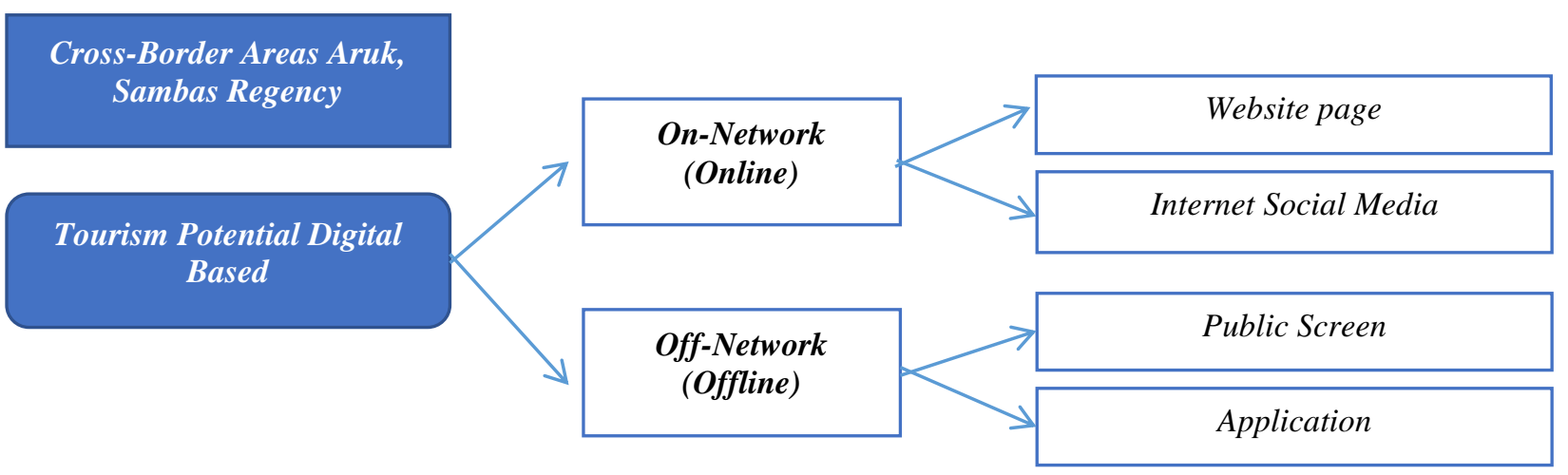

Source: Processed by researchers (2020)

Things that used to be obstacles can then be processed into these benefits supported by the use of digital-based technology and information that prioritizes promotion through social media and facilitating services. One of the ways that the Ministry of tourism has taken in developing this potential is by empowering the youth movement through the Pesona Indonesia Generation (GenPI) and the Wonderful Indonesia Generation (GenWI).

However, with the still presence of Covid-19, this causes tourists to choose tourist areas that are not far from their home or country area. Third, young tourists from the upper-middle class are more eager to travel; Fourth, natural attractions are more popular for tourism, this is because tourists think that it is easier to maintain distance when doing tours in nature. The difference from tourism is carried out by animal gardens or places that are less open. The fifth and the last consumers need a new travel experience-individually based; doing individually-based makes it more like traveling to tourist attractions and tourists don't need to think too much about social distension. Maybe this activity is very much done.

The general chairman of the National Generation of Enchantment of Indonesia, Mansyur Ebo, in a seminar entitled Cross Border Digital Destinations in Batam, Riau Islands from 6 to 8 December 2018, revealed that to realize the objectives of the Digital Cross Border, the Ministry of Tourism also relies on the involvement of the Generation Pesona Indonesia forum. He also hopes that the activation of this forum can also support the achievement of the target of 20 million foreign tourists visiting Indonesia and 275 million domestic or domestic tourists [19].

The Minister of Tourism of the Republic of Indonesia, Arief Yahya said that tourism must follow global technological developments, be closer to tourists, and be more professional for this, the Ministry of Tourism formed the Indonesian Enchantment Generation (GenPI) and the Wonderful Indonesia Generation (GenWI). The Pesona Indonesia Generation (GenPI) in West Kalimantan has to promote the tourism potential of West Kalimantan by its members in the country.

Meanwhile, Generasi Wonderful Indonesia is a forum for youth whose members are abroad with the same task, namely promoting tourism through social media. The role of increasing the promotion of tourism potential through the Generation Pesona Indonesia and GenWI forum is carried out by utilizing digital media or digital destinations. One of the programs implemented by the Pesona Indonesia Generation of West Kalimantan is the GenPI Roaming Program. This program is implemented by exploring tourist objects in four districts/cities, namely in Sanggau, Bengkayang, Sintang, and Kapuas Hulu. This program is also part of the partnership between GenPI and the West Kalimantan Youth, Sports and Tourism Office which aims to make cross-border tourism more widely known by the community to foreign countries.

\section{CONCLUSION}

In this era, various kinds of tourism activities and supported by various facilities and services provided by the community, businessmen, government, and local governments. Seen from this understanding, it indicates that there is a link between one party and another in realizing good tourism, especially in the current digital era. The development of digital-based literacy tourism should reach out in cross-border areas including Aruk, Sambas Regency, and the Aruk border into the Wonderful Indonesia Calendar of Events (CoE) launched by the Ministry of Tourism. Tourism is one of Indonesia's strategic sectors to increase Indonesia's 
economic figures. The potential of natural, cultural, and local wisdom possessed by each region in Indonesia, including in the border area, which is an attraction for both local and foreign tourists. Based on various data the authors obtained, it was found that the tourism sector was paralyzed when faced with the impact of the Covid-19 pandemic, including border tourism. The results of the study found that the formation of both was carried out to increase tourism promotion through social media. Also, the use of information technology by the current millennial era is carried out so that Indonesian tourism can compete in the international arena. This research finds that based on strengthening border tourism during Covid-19 has been carried out through of political boundaries perspective by understand and implement the Covid-19 border tourism adaptation policy, strengthening the political potential of border tourism during Covid-19, and developing digital-based border tourism during Covid-19.

\section{REFERENCES}

[1] H. Zamani-Farhani, "Host attitudes toward tourism: A study of Sareyn Municipality and local community partnerships in therapeutic tourism," J. Tour., vol. 2, no. 1, pp. 16-34, 2012, [Online]. Available:

pdfs.semanticscholar.org. (Accessed: 4 August 2020).

[2] T. A. Wibowo and Y. Sunantri, "Inventory And Tourism Opportunities In Sekupang-Batam District," Proceeding ICOGISS 2019, pp. 892898, 2019, [Online]. Available:

https://www.bps.go.id/dynamictable/2018/05/18 /1337/persentase-panjang-jalan-tol-yangberoperasi-menurut-operatornya-2014.html. (Accessed: 5 August 2020).

[3] B. B. Erdogru and H. N. T. Yazici, “Advantages of Football Tourism within the framework of Sustainable Tourism Model study A Mediterranean City Antalya," Int. J. Trade, Econ. Financ., vol. 4, no. 6, pp. 372-375, 2013, doi: 10.7763/ijtef.2013.v4.319. [Online]. Available: http://www.ijtef.org. (Accessed: 4 August 2020).

[4] D. J. Timothy, "Political Boundaries And Tourism: Borders As Tourist Attractions," Tour. Manag., vol. 16, no. 7, pp. 525-532, 1995, doi: 10.1016/0261-5177(95)00070-5. [Online].

Available:

https://www.sciencedirect.com/science/article/a bs/pii/0261517795000705. (Accessed: 5 August 2020).

[5] M. Her, "How is Covid-19 affecting South Korea? What is our current strategy?," Disaster Med. Public Health Prep., pp. 4-6, 2020, doi: 10.1017/dmp.2020.69. [Online]. Available: https://www.cambridge.org/core/journals/disaste r-medicine-and-public-healthpreparedness/article/how-is-covid19-affectingsouth-korea-what-is-our-currentstrategy/0EA2D469C3131FBDD0110922FCD4 EF7E. (Accessed: 5 August 2020).

[6] M. Martoyo, E. Elyta, H. Herlan, and A. Arifin, "Economic Development and Sustainable Human Resources by Supply Chain Managament in Government Towards in West Kalimantan Indonesia," Int. J. Supply Chain Manag., vol. 9, no. 2, pp. 1054-1063, 2020, [Online]. Available: https://ojs.excelingtech.co.uk/index.php/IJSCM/ article/view/4765. (Accessed: 4 August 2020).

[7] T. Andrianto, "The Halal-Ness Hospitality On Halal Tourism, Case Study Of Halal Restaurant In Bandung, Indonesia," J. Indones. Tour. Hosp Recreat., vol. 2, no. 2, pp. 210-222, 2019, doi: 10.17509/jithor.v2i2.21001. [Online].

Available:

https:/ejournal.upi.edu/index.php/Jithor/article/ view/21001. (Accessed: 4 August 2020).

[8] D. Kuswaraharja, "Infografis: Jumlah Turis Asing April 2020 Anjlok Tajam,” Detik, 2020. [Online]. Available:

https://travel.detik.com/travel-news/d5037946/infografis-jumlah-turis-asing-april2020-anjlok-tajam. (Accessed: 6 August 2020).

[9] D. Metodijeski and Z. Temelkov, "Tourism Policy of Balkan Countries: Review of National Tourism Development Strategies," UTMS J. Econ., vol. 5, no. 2, pp. 231-239, 2014, [Online]. Available: http://eprints.ugd.edu.mk/11635/. (Accessed: 6 August 2020).

[10] Tempo, "Membangun Konektivitas 10 Kawasan Strategis Pariwisata Nasional," Tempo, 2018. [Online]. Available: https://inforial.tempo.co/info/1000761/memban gun-konektivitas-10-kawasan-strategispariwisata-nasional. (Accessed: 4 August 2020).

[11] Z. Kirovska, "Strategic Management Within the Tourism and The World Globalization," $J$.

Econ., vol. 2, no. 1, pp. 69-76, 2011, [Online]. Available:

https://www.econstor.eu/handle/10419/49234. (Accessed: 4 August 2020).

[12] B. Petrevska, "Tourism in the Global Development Strategy of Macedonia: Economic Perspectives," UTMS J. Econ., vol. 2, no. 1, pp. 101-108, 2011, [Online]. Available: http://eprints.ugd.edu.mk/11604/. (Accessed: 4 August 2020).

[13] Elyta, H. Almutahar, and Z. Saing, "National Strength on Construction of International 
Freight Terminal in Entikong Indonesia," Int. J. Sci. Technol. Res., vol. 8, no. 3, pp. 10-15, 2019, [Online]. Available: http://www.ijstr.org/finalprint/mar2019/National-Strength-OnConstruction-Of-International-FreightTerminal-In-Entikong-Indonesia.pdf. (Accessed: 6 August 2020).

[14] I. N. Sudiarta and P. E. Wirawan, "Development Strategy Of Jogging Track As Tourist Attraction In Anggabaya Village, Penatih Denpasar," JBHOST, vol. 4, no. 1, pp. 51-58, 2018, doi.org/10.1016/j.cell.2017.12.025\%0A [Online]. Available:

http://www.depkes.go.id/resources/download/in fo-terkini/hasil-riskesdas-

2018.pdf\%0Ahttp://www.who.int/about/licensin g/. (Accessed: 6 August 2020).

[15] A. M. Ghețe, "Classification of Various Forms of Tourism," Ann. Univ. Oradea Econ. Sci., vol. 25, no. 2, pp. 313-319, 2016, [Online].

Available: https://doaj-

org.ezproxy.aut.ac.nz/article/b16ea21c23ab4fc6 9e9c1f35382fd23d\%0Ahttp://esc-

web.lib.cbs.dk/login?url=http://search.ebscohost .com/login.aspx ?direct $=$ true $\& d b=b$ th $\& A N=120$ $823157 \&$ site $=$ ehost-live $\&$ scope $=$ site.

(Accessed: 5 August 2020).

[16] A. Kagermeier, L. Amzil, and B. Elfasskaoui, "The transition of governance approaches to rural tourism in southern Morocco," Eur. J. Tour. Res., vol. 23, no. January, pp. 40-62, 2019, [Online]. Available:

https://www.researchgate.net/publication/33231 9529_The_transition_of_governance_approache s_to_rural_tourism_in_Southern_Morocco. (Accessed: 4 August 2020).

[17] G. Ramdhani, "Perkuat Crossborder Kalimantan, Kemenpar Gelar FGD CoBranding," Liputan 6, 2019. [Online]. Available:

https://www.liputan6.com/lifestyle/read/394031 1/perkuat-crossborder-kalimantan-kemenpargelar-fgd-co-branding. (Accessed: 4 August 2020).

[18] B. Meyer and A. Gardzińska, "Development of Tourism in a Cross-Border Area on the Example of the Zachodniopomorskie Voivodship and Mecklenburg-Vorpommern," Barom. Reg. Anal. i prognozy, vol. 1, no. 47, pp. 89-96, 2017, [Online]. Available:

http://cejsh.icm.edu.pl/cejsh/element/bwmeta1.e lement.desklight-9ce5f3ec-9ed3-4320-867f4b2d67b6d8a1. (Accessed: 4 August 2020).

[19] M. Yunita, "Gandeng GenPI, Kemenpar Garap Potensi Destinasi Digital di Perbatasan," Suara, 2018. [Online]. Available: https://www.suara.com/lifestyle/2018/12/07/120 000/gandeng-genpi-kemenpar-garap-potensidestinasi-digital-di-perbatasan. (Accessed: 4 August 2020).

[20] Kemenpar and CNN Indonesia, "Kemenpar Garap Potensi Destinasi Digital di Perbatasan," CNN Indonesia, 2018. [Online].

Available:https://www.cnnindonesia.com/gayahidup/20181207164239-269-351930/kemenpargarap-potensi-destinasi-digital-di-perbatasan. (Accessed: 5 August 2020).

[21] MC Provinsi Kalimantan Barat, "Pemprov Kalbar Gelar Wisata Literasi Nasional 2019," Info Publik, 2019. [Online]. Available: http://infopublik.id/kategori/nusantara/371784/p emprov-kalbar-gelar-wisata-literasi-nasional2019. (Accessed: 4 August 2020).

[22] M. P. Nagari and E. Pangestusi, "Peran Digital Tourism Dalam Pengembangan Kampung Wisata Jodipan," vol. 74, no. 1, pp. 48-54, 2019, [Online]. Available:

administrasibisnis.studentjournal.ub.ac.id. (Accessed: 6 August 2020).

[23] R. M. F. Carvalho, C. Costa, and A. M. Ferreira, "Community Based Tourism Festivals In The Médio Tejo Region, Portugal - A Potential For The Specialized Cultural Consumption Of Creative Tourism," Int. Congr. Tour. - Tour. 21st Century, pp. 1-24, 2015, [Online].

Available:

http://comum.rcaap.pt/handle/10400.26/29012. (Accessed: 4 August 2020).

[24] B. Włodarczyk, "Space In Tourism, Tourism In Space: On The Need For Definition,

Delimitation And Classification," Turyzm, vol. 24, no. 1, pp. 25-34, 2004, doi: doi:10.2478/tour-2014-0003. [Online]. Available: https://econpapers.repec.org/article/vrstouris/v_ 3a24_3ay_3a2014_3ai_3a1_3ap_3a10_3an_3a3 .html. (Accessed: 4 August 2020).

[25] Den, "Club Motor Malaysia Kepincut Pesona Festival Crosborder Entikong," Indonesia Travel News, 2019. [Online]. Available: https://www.indonesiatravel.news/pariwisata/clu b-motor-malaysia-kepincut-pesona-festivalcrosborder-entikong/. (Accessed: 6 August 2020).

[26] L. A. Azanella, "Daftar 100 Negara Teraman dari Covid-19, Indonesia Urutan 97," Kompas, 2020. [Online]. Available:

https://www.kompas.com/tren/read/2020/04/28/ 172650765/waspada-ada-49563-kasus-demamberdarah-di-indonesia-selama-2020. (Accessed: 5 August 2020). 
[27] P. N. Acha-Anyi, "Planning and development of sustainable tourism products in local communities," African J. Hosp. Tour. Leis., vol. 5, no. 3, pp. 1-20, 2016, [Online]. Available: www.ajhtl.com. (Accessed: 6 August 2020).
[28] S. Tanaś, "Tourism 'Death Space' and Thanatourism in Poland," Curr. Issues Tour. Res., vol. 3, no. 1, pp. 22-27, 2013, [Online]. Available:

http://citr.up.krakow.pl/article/view/1376. (Accessed: 4 August 2020). 